\title{
Education for Appreciating Environment-An Example of Curriculum Design of Natural Aesthetic Education in Taiwan
}

\author{
Chung-Ping Yang ${ }^{1}$ \\ ${ }^{1}$ Graduate Institute of Education, National Changhua University of Education, Taiwan \\ Correspondence: Chung-Ping Yang, Graduate Institute of Education, National Changhua University of \\ Education, No.1, Jin-De Road, Changhua City 500, Taiwan. Tel: 886-4-723-2105-2231. E-mail: \\ cpyang@cc.ncue.edu.tw
}

Received: November 20, 2014 Accepted: January 6, 2015 Online Published: April 28, 2015

doi:10.5539/ies.v8n5p88

URL: http://dx.doi.org/10.5539/ies.v8n5p88

\begin{abstract}
Environmental protection is now the common consensus in the world. If we can teach students how to appreciate the natural environment and love its beauty, they may protect the environment naturally. But how can we learn to appreciate nature? The research on the contemporary aesthetics of nature provides rich discussions and directions. This paper uses literature analysis as the method to examine the main contents of the Western aesthetics of nature and to develop an example of curriculum design. There are two models-a cognitive approach and a non-cognitive approach-in the aesthetics of nature. The former stresses the necessity of scientific knowledge, including ecology, biology, and geography, while the latter focuses more on imagination, intuition, mystery, and folktales. After analysis and review of the two models, I induce them into nine principles of appreciation. Furthermore, I suggest some principles of teaching, such as Cornell's "flow learning," art creation, and raising plants or insects by oneself. Finally, according to these principles and teaching methods, I design an example of a curriculum for elementary school students in Taiwan. I will present a unit of frame to provide details about the curriculum and how to teach the appreciation of nature.
\end{abstract}

Keywords: curriculum design, aesthetics of nature, environmental appreciation, natural aesthetic education

\section{Introduction}

At a time when environmental problems (e.g., global warming, resource depletion, environmental pollution, climate anomalies, loss of biodiversity, deforestation, and improper development) are being exacerbated, numerous developed countries have not only shown increasing concerns pertaining to the policies, regulations, and general promotion of environmental protection and recovery, they have also placed an increasing emphasis on environmental education. In Taiwan, environmental education is listed as one of the seven key educational issues following the Grade 1 to 9 Curriculum reform, encouraging teachers to integrate environmental education into the various school subjects. In response, numerous elementary and junior high schools have subsequently established websites and formulated executive plans pertaining to environmental education, and have further promoted various environmental subjects, courses, and activities. In addition, the regional education units in Taiwan have established environmental education and counseling groups in their individual jurisdictions. These efforts thus imply that environmental education has become a key concern in elementary and junior high schools.

Based on the descriptions released by the Department of Education (2008), environmental education encompasses 5 key aspects, namely environmental awareness, environmental sensitivity, conceptual knowledge and connotations, ethics and values, and skills and experiences regarding environmental activities. Although all 5 aspects are of equal importance, environmental awareness is the foundation upon which the remaining aspects are based; thus, environmental awareness entails the training of students' sensory awareness abilities (i.e., observing, classifying, sequencing, determining spatial relationships, measuring, inferring, predicting, analyzing, and interpreting), consequently enhancing their awareness toward environmental damage and pollution, and their appreciation and sensitivity toward environmental aesthetics. The driving force for action is be touched and enthusiasm for the beauty of natural environment. As the essential first step to environmental education, schools should create outdoor education opportunities to aid students in experiencing nature, thereby cultivating students' appreciation and respect for nature (Chang, 2001).

Aesthetic motive powers are a type of internal preference that induces voluntary reactions, whereas moral 
imperatives may not necessarily be preferred. If an interest and ability to appreciate natural beauty were extensively embedded into students' environmental awareness at a young age, then students would consequently become environmental monitors who would then voluntarily take responsibility for conservation because they are urged to protect objects they favor. Thus, aesthetic imperatives more effectively stimulate mobility than moral imperatives, suggesting that students' ability to appreciate for natural beauty is the foundation for their environmental protection incentives.

However, converting students' personal experiences into appreciation and awareness toward natural beauty presents considerable challenges, amplifying the significance of natural aesthetic education. In Taiwan, aesthetic education is considered a variant of arts education, which includes music, arts, and performing arts. Although instances where environmental arts have been introduced in creative teaching, these lessons typically teach students to create environmental artwork out of various waste products, such as wood, tires, CDs, Styrofoam, paper boxes, and rope, but fail to teach students to appreciate natural beauty. Although natural beauty are mentioned in Chinese, social studies, and science and life technology lessons, the core focus is not on natural aesthetic appreciation, but on literature-related skills, and environmental knowledge. Consequently, the majority of environmental education curricula implemented in schools emphasizes recycling and reusing, waste classification and reduction, understanding environmental pollution, the greening and beautification of school grounds, and understanding school ecology, while failing to teach natural aesthetic appreciation. Therefore, by investigating theories of aesthetics of nature, this study proposes a curriculum design model that can be provided as a reference to elementary schools when implementing natural aesthetic education.

\section{Problems with Teaching Environmental Appreciation in Taiwan}

Environmental education in Taiwan focuses on awareness and sensitivity, with performance indicators that pertain to "the ability to perceive the animals, plants, and landscapes in a natural environment using bodily senses, thereby receiving inspiration and appreciating the aesthetics of nature," and "the ability to observe and experience nature, and consequently present the aesthetics of the natural environment and show environmental awareness through writing, art, music, or theatrical performances" (Department of Education, 2008). However, related curricula and teaching methods adopted by elementary and junior high schools in Taiwan hinder the expected performance of environmental education. For example, at elementary schools, the Chinese, social science, and nature and life technology textbooks employed typically contain and mention nature and environmental issues, but fail to teach natural aesthetic appreciation. Chinese classes typically focus on students' semantic analysis and rhetoric skills, and Chinese teachers are more concerned with the appreciation of poems and verses; in other words, Chinese uses nature to realize the aesthetics of literature, and not the appreciation of nature itself. Social studies and nature and life technology involve a substantial amount of geographic and natural environment content; yet this content is based on knowledge teaching that separates knowledge from appreciation. Although elementary school students do not experience substantial academic pressure, natural aesthetic appreciation cannot be achieved solely on the content of teaching materials. Without the natural appreciation attainment of the teachers, students may only develop the ability to appreciate sensory beauty. Based on the current "nature and life technology" lessons in elementary schools, environmental awareness content primarily focuses on observing and perceiving the sensory attributes of nature, environmental damage, and pollution, and lack the appreciation of nature. Subsequently, the biological images presented to elementary school students, although beautiful, are used for cognitive explanations and lack appreciation incentive.

Numerous schools have additionally formulated various environmental education plans, encompassing recycling, waste reduction, energy conservation and carbon reduction, environmental art creation, campus greenification and beautification, green schools, and school ecology awareness. However, natural appreciation is not highlighted in these plans, and may not even be included in the expositions. These plans emphasize the protection, and not the appreciation, of nature, and the majority of them remain focused on the teaching of ecological knowledge within the school campus, such as plants, insects, and birds, but lack the incentive for appreciating nature. Exampling the environmental education curriculum of an elementary school in Taiwan (Cun Dong Elementary School, 2014), the teachers of this school devised and distributed a Palm Tree handout among the students, teaching them in identifying the different characteristics between Bottle Palms, Spindle Palms, and Yellow Areca Palms, such as fruit, trunk segments, and segment rings, and further aiding them in appreciating the aesthetics of nature. If specific open questions were included in this handout, it could not only stimulate students' memory toward scientific names, but also more effectively enhance students' aesthetic perceptions. These types of questions can include, "Do you think the bottle palm is pretty? Why?" "What does it look like? (e.g., beer belly)" "If you were told that the bottle palm presents a life cycle of 50 years, originates from the Masarene Islands, and plays a unique role in ecological systems, what would you think?" "Do you think that it 
has a miraculous way of living?" "If you were that bottle palm, how would you feel?" and "Do you know when the bottle palm first appeared on earth?"

In summary, the natural appreciation aspect of environmental awareness is not particularly emphasized in elementary schools in Taiwan. Natural beauty is neither a teaching focus in academic subjects, nor one in general environmental education plans. Despite the importance of natural aesthetic appreciation, this aspect fails to receive due attention and incentive. This could possibly be because teachers lack the professional ability to teach natural appreciation, as well as because of the neglect and shunting of natural aesthetic education caused by the insufficient conceptual foundation provided by previous aesthetic studies.

\section{Main Contents of Aesthetics of Nature}

How to teach natural beauty? The research on the aesthetics of nature provides rich discussions and directions. Essentially, the aesthetics of nature can be divided into the following two approaches: the cognitive approach and the non-cognitive approach (Brady, 2003; Carlson, 2009) (Note 1).

\subsection{The Aesthetics of Nature of the Cognitive Approach}

What are the appropriate or correct ways for appreciating nature? Carlson suggested the "natural environmental model," which has since become a famous paradigm. According to Carlson, to possess "common-sense / scientific knowledge" relevant to nature is the key factor to generate an aesthetic sense and appreciate nature correctly. We need to know related scientific knowledge about prairies, wetlands, deserts, or forests in order to know how to pay attention to each environment's uniquely rich content and detail. Without such knowledge, we may miss deep aesthetic qualities or engage in the wrong type of appreciation. For Carlson, natural scientific knowledge, such as geology, geography, biology, and ecology, is more important than common sense as it can enable us to see beauty where we could not see it before (Carlson, 2002a).

In fact, Carlson does not afford too many useful directions in terms of appreciation. As a supporter of Carlson's scientific model, Rolston offers more suggestions for appreciation. Rolston claims sciences provide profound knowledge to help us appreciate nature and discover various aesthetic properties. He rejects limiting aesthetics to the beauty perceptible to the senses, and expands it to include beauty sensed by the reasoning mind. For Rolston, the aesthetics of nature should stress concepts as well as percepts (Rolston, 1995, 2011).

Natural sciences help us find the beauty of diversity and the abundance of creatures; the aesthetic sense of ancient time and space; the beauty of each organism's sublimity and subtlety; and the beauty of the struggle for survival and regeneration. For example, ferns, club moss and Sphagnum are ancient plants which can make us enjoy the aesthetic experience of deep time and space. Sundews, pitcher plants and Venus flytraps develop special methods to catch insects for survive. These exquisite skills and ingenuities are marvelous and can evoke a deep sense of aesthetic (Rolston, 2000). If we can look beyond colors and appearance in order to see some "ugly" plants or animals from an ecological view, we may find that they are actually quite beautiful.

\subsection{The Aesthetics of Nature of the Non-Cognitive Approach}

However, some scholars do not agree with the scientific model and, instead, stress emotion, engagement (or immersion), mystery, imagination and religion. Carroll argues that we are just being emotionally moved or aroused by nature when appreciating nature. When we are standing under a thundering waterfall, our ears are echoing with the roar of falling water, and we are overwhelmed and excited by its height and grandeur, thus we do not need any scientific knowledge (Carroll, 2004). But for Carlson, emotion is subjective and cannot be the appropriate basis of the appreciation of nature. Science provides more rich cognition and deep appreciation than senses and emotion (Carlson, 2002a). But is science objective? Is emotion subjective? Even scientific knowledge is richer and deeper than common sense, but can we say that aesthetic appreciation rooted in the basis of scientific knowledge is more 'deeper?'

In addition to Carroll, Berleant (1997) also opposes Carlson's theory and stresses the "engagement model." People observe the world by using their body and mind, not thinking. Therefore, appreciating nature means immersing oneself in the object and diminishing the distance between subject and nature. Brady (1998) holds that imagination plays a central role in the appreciation of nature. She divided imagination for appreciating nature into the following four models: exploratory imagination, projective imagination, ampliative imagination, and revelatory imagination. For example, if I go to a forest, I may imagine that the gestures of an old tree look like a dancing woman, and the tree reveals the vitality and creation of our beautiful earth. All of these forms of imagination enrich my feeling and thinking, enabling me to have a deep aesthetic experience and a sense of awe, respect, and wonder for the tree. Likewise, Hepburn (2004) holds a "metaphysical imagination model." This means that we should imagine the metaphysical characters of nature like as "oneness with nature," the 
co-presence of opposites, sublimity, and infinity when appreciating nature. For example, with respect to "the co-presence of opposites," we can imagine a still rock also possess the power of being active before. As for Rolston, to enter a forest makes us feel a kind of timelessness, antiquity, and continuity, even eternity, which causes some people to move toward the sublime and sacredness of God (Rolston, 1998) (Note 2). Natural beauty makes some people feel the love and creation of God, causing such people to turn to a religious aesthetic appreciation.

Actually, both the cognitive approach and the non-cognitive approach reveal some valuable insights for the appreciation of nature. The debate between these two approaches involve the meaning of science, cognition, emotion, imagination, and aesthetic experience, which further enriches research on the aesthetics of nature. It is difficult to insist which model is richer and deeper than the rest. Although scientific knowledge may indeed deepen appreciation, other models may also make our appreciation richer. Saito argues that Carlson's perspective is too narrow, adding that some folktale, myths, and indigenous traditions can also help deepen appreciation for nature. They use both stories and the sciences to talk about nature (Saito, 2004). Otherwise, the history related to the change and development of a landscape is also an important element for appreciation. For instance, if we want to appreciate Mount Rushmore, we have to understand the history of the sculptures of the four United States presidents that are carved in the mountain (Carlson, 2002b). Various arts can also help us to appreciate natural beauty. Artists explore deep aesthetic qualities of nature and present them to us. For example, in his famous book "Walden", Thoreau (1817-1862) (1990) said a diving bird playing the game of hide-and-seek with him in Walden Lake. The diving bird would dive down into the water and appeared in the other place of the lake when Thoreau rowed to it. Then the bird would like as a naughty child laughed at him, which made us feeling the beauty of interaction between human and animal. Goatsuckers, foxes and birds sang songs together. The lake was a tender poetry in the night. Thoreau helped us to appreciate the beauty of harmony, peace and freedom of the lake. By use these approaches, teachers can help students to develop a greater appreciation for nature. Appreciating life's subtlety helps them to realize that life's existence is very precious. The beauty of the struggle for life can motivate people and encourage us to move forward and positively face all kinds of challenges in life. If a tiny flower can show beauty in the bitter winter, there is nothing unattainable in life. If school education can make good use of natural beauty as life education materials, it will help students to appreciate nature and will thus be reflected in their lives, allowing them to respect themselves, others, and nature. Accordingly, regarding the educational aim of improving appreciation, senses, natural sciences, imagination, engagement, myth, history, folktale, religion, and arts can all be an important element for appreciation. Integrating the merits of these models and principles into the curriculum could have positive effects in terms of cultivating students' competence to appreciate nature and fostering environmental perceptual awareness in the teaching of environmental appreciation. These elements include the following:

Table 1. Nine types of aesthetic sensitivity

\begin{tabular}{lll}
\hline $\begin{array}{l}\text { Types } \\
\text { aesthetic } \\
\text { sensitivity }\end{array}$ & of & Explanation \\
\hline 1 Senses & $\begin{array}{l}\text { The aesthetic sensitivity of forms, colors, sounds, touches, and smells that originate from various } \\
\text { types of natural environments through the five senses organs. }\end{array}$ \\
& $\begin{array}{l}\text { (Note 3) } \\
\text { Science }\end{array}$ & $\begin{array}{l}\text { Discover the beauty of diversity and abundance of creatures; the aesthetic sense of ancient time and } \\
\text { space; the beauty of delicacy, sublimity, and subtlety; and the beauty of the struggle for survival and } \\
\text { regeneration through the knowledge of natural sciences such as ecology, biology, geography, } \\
\text { geology, botany, etc. }\end{array}$ \\
\hline
\end{tabular}


3 Imagination Aesthetic sensitivity through imagination, examples of which include the following:

Formality imagination: imagine being someone or something. For example, imagine being a cloud, a mountain, or a fish.

Projective imagination: imagine oneself being someone or something surviving under a certain circumstance, such as a flower that lives on a lofty mountain.

Cause imagination: imagine how something was created; why and how it was created; and what it was like before it was created. For example, imagine a round stone on a beach which was formed due to the waves of the sea. Try to imagine the original shape of the rock.

Historical imagination: imagine the history of something. For example, imagine the history of an ancient forest.

Metaphysical imagination: imagine the unity, co-presence of opposites, sublimity, absolute, infinity, etc. For example, imagine the infinity of the universe beyond the sky.

4 Engagement

Active participation in the world; personally experiencing the beauty of nature through the body and soul.

5 Myth

Aesthetic sensitivity through myths. For example, understand the story of "Chang-Er Reaches Moon" in order to appreciate the aesthetic sensitivity of the moon; aboriginal people's myths and stories can also cultivate a richer appreciation for the beauty of nature.

6 History

Aesthetic sensitivity through comprehension of humanity history. For instance, contemplate the divine tree that was cut down and left a mark on the Alishan Mountain in Taiwan during the era of Japanese colonization; such exercises help us to appreciate the beauty of the local environment.

$7 \quad$ Folktale

Aesthetic sensitivity through folktales. For example, before scientists named the bird, the local men at Tainan in Taiwan discovered that the bird uses its bill to stir its food, just like a stirring spoon; as a result, they named the bird the "Stirring bird." Thus, the local men grasped the characteristic of the black-face spoonbill quite well.

8 Art Discover the characteristics of nature's beauty through literature, painting, music, etc.

9 Religion Understanding the Buddhist concept of "the impermanence of all things" and the Christian concept "the world of creation" can also help us appreciate the beauty of the natural environment.

\section{Curriculum Design of Aesthetic Appreciation of Nature}

\subsection{Teaching Methods of Natural Aesthetic Education}

These nine principles of appreciation could serve as guide for the curriculum design of natural aesthetic education. But good teaching methods are important equally and can make the curriculum more effective and active. I propose the following three teaching methods:

\subsubsection{Flow Learning}

In natural aesthetic education, flow learning was developed by Cornell and has since become a widely used model. To cultivate participants' sensitivity to nature, flow learning emphasizes the following four steps (Cornell, 1998; Tu, 2009):

(a) Awaken enthusiasm: experiencing nature through role-playing games. For instance, ask students to imitate the four seasons of a tree or to be the water that travels around the earth. Another example is to ask someone to volunteer to imitate a bat and play the game of the "bat chasing the moth." The teacher could also find an elegant poem about nature and read it aloud.

(b) Pay attention: focus your five senses on one particular object that you are interested in.

(c) Direct experience: for example, hugging a tree; talking to a tree; imagining oneself as a leaf on the branch of a tree; observing the flowing clouds in the sky; or feeling the gentleness of the wind while closing one's eyes.

(d) Sharing inspiration: everyone would share his or her experience, including what they sensed after the activity.

\subsubsection{Creativity and Sharing the Arts}

Feelings and sensitivity are often hard to describe in words. As a result, if a student is able to demonstrate sensitivity and feeling through art, including creative writing, poetry, painting, drama, etc., the instructor 
would be able to comprehend what the student had learned. Thus, students can present richer and deeper manifestations of their ideas through the creation of art.

\subsubsection{Raising Plants or Insects by Oneself}

Students cannot cultivate deep sensitivity if teaching only consists of static lectures or pictures. However, appreciating live natural things in the classroom is also transient and does not allow for a long period of appreciation. In principle, teachers may enable students to have more intimate interaction with nature as much as possible, including, for example, by raising flowers, little trees, or insects. However, teachers should consider the ecologic problems related to dealing with living things when teaching as well. Therefore, raising tomato, rice, flower or butterfly may be a better activity.

\subsection{Curriculum Design of Natural Aesthetic Education}

According to the nine principles of appreciation and teaching methods listed above, I designed the following example (Table 2) of a curriculum for elementary school students. The curriculum has seven units, including categories for animals, plants, wetlands, and stars. Each unit should last between 280 to 360 minutes in total.

Table 2. Seven curriculum units of natural aesthetic education

\begin{tabular}{|c|c|c|c|}
\hline & Unit & Lesson & $\begin{array}{l}\text { Time } \\
\text { (Min.) }\end{array}$ \\
\hline \multirow[t]{4}{*}{1} & $\begin{array}{l}\text { The } \\
\text { Prince }\end{array}$ & $\begin{array}{l}\text { 1. Students search for frogs residing in the school's ecological ponds, and subsequently conduct } \\
\text { ecological investigations and record their observations. }\end{array}$ & 320 \\
\hline & & $\begin{array}{l}\text { 2. Students gain understanding the beauty of the outer characteristics of the frogs, such as } \\
\text { sounds, color, and body shape. }\end{array}$ & \\
\hline & & $\begin{array}{l}\text { 3. Teachers teach students the ecological science, myths and folk stories pertaining to frogs, } \\
\text { guiding them to appreciate the aesthetics of frogs. }\end{array}$ & \\
\hline & & $\begin{array}{l}\text { 4. Teachers separate the students into groups to perform the Frog Prince, and to make paintings } \\
\text { and drawings of frogs. }\end{array}$ & \\
\hline \multirow[t]{4}{*}{2} & $\begin{array}{l}\text { Dancing } \\
\text { with Tree }\end{array}$ & $\begin{array}{l}\text { 1. Using trees that are common to the school and everyday life as examples, teachers teach } \\
\text { students to appreciate the external aesthetics of various tree types, introducing the related } \\
\text { botanic and ecological knowledge. }\end{array}$ & 280 \\
\hline & & $\begin{array}{l}\text { 2. Students discuss the myths and folk stories pertaining to various trees, aiding them in } \\
\text { appreciating tree aesthetics. }\end{array}$ & \\
\hline & & $\begin{array}{l}\text { 3. Teachers introduce illustrations and novels involving trees, facilitating students to appreciate } \\
\text { nature through art. }\end{array}$ & \\
\hline & & $\begin{array}{l}\text { 4. Teachers separate students into groups to play the roles of different trees, instructing them to } \\
\text { participate in games and compose poetry relating to ecology. }\end{array}$ & \\
\hline \multirow[t]{3}{*}{3} & $\begin{array}{l}\text { The Beauty } \\
\text { of Tomatoes }\end{array}$ & $\begin{array}{l}\text { 1. The school establishes a tomato garden within the school grounds. Students are allocated } \\
\text { with a section of arable land in which they grow their own tomatoes and periodically record } \\
\text { growth conditions. }\end{array}$ & 320 \\
\hline & & $\begin{array}{l}\text { 2. Teachers provide students with scientific knowledge, myths, and folk stories regarding the } \\
\text { various species of tomato, enhancing their aesthetics appreciation ability. }\end{array}$ & \\
\hline & & $\begin{array}{l}\text { 3. The school arranges harvest ceremonies, food tastings, and exhibitions in which students can } \\
\text { display their observational findings. }\end{array}$ & \\
\hline
\end{tabular}


4 Find 1. Students are instructed to observe the wildlife of Fubow Wetlands located in Changhua 360

Wetlands County, Taiwan, including fiddler crabs, mudskippers, and migrating birds.

2. Teachers initially provide students with explanations and films relating to natural science and ecology within the classroom, enhancing the students' appreciation toward the imagery of wetland ecology.

3. The school invites personnel from the Changhua Nature Conservancy to provide outdoor guidance and explanations.

4. Teachers play games with students in the classroom, instructing them to imitate wetland ecology.

5. By showing students photography and illustrations relating to wetland ecologies, teachers teach students to appreciate wetland aesthetics.

5 Endless Butterflies

6 Flowery Tricks

$7 \quad$ Stargazing

1. Teachers instruct students to individually grow a plant and care for a caterpillar. The students must then observe and record the growth of their butterfly by writing articles, composing poems, drawing pictures, capturing images, or directing films.

2. Teachers introduce and explain the butterfly ecology using pictures, the Internet, and films, enhancing the students' sensory aesthetics appreciation.

3. Teachers employ imagination activities pertaining to butterflies, facilitating students in acquiring imagination aesthetics.

4. Teachers provide students with scientific knowledge, myths, and folk stories, enhancing their appreciation toward butterfly aesthetics.

5. Teachers play the outdoor game, mantis prey butterflies, and also carry out the ceremony, farewell butterflies, with students.

6. Teachers instruct each student to compile the information provided to them throughout the unit into a small book, and to share their experiences with the class.

1. Teachers teach students the aesthetics of various flowers within the school campus and the surrounding community.

2. Teachers explain to students how to appreciate the appearance aesthetics of flowers and introduce botanical and ecological knowledge.

3. Teachers select several species of flower in the school and surrounding community, and introduce the myths, folk tales, and religious stories based on these flowers.

4. Students undergo imagination activities and compose articles relating to flowers.

1. Students are instructed to observe the starry night sky, and teachers facilitate students in appreciating related aesthetics by providing them with a set of instructions. These instructions include telling students to observe the starry sky, consider what living or non-living object the constellations represent, imagine themselves to be stars, and image countless eyes looking back at them. Teachers further propose questions, such as "How many people do you think have observed the stars in the past, and which stars did they see at that time?" and "Where are these people now?" These questions allow the students to imagine the infinite and historical value of the universe.

2. Teachers teach students the astronomical knowledge of the stars, aiding them in developing appreciation toward the aesthetics of ancient time and space.

3. Teachers introduce related myths (e.g., the cow herder and the weaver girl, the myth of Ursa Major, and the Greek myths of the 12 constellations) and folk stories, amplifying students' appreciation of the stars.

4. Students are taught to appreciate illustrations and music relating to stars.

5. Based on stars, students are separated into groups to compose poems, draw pictures, and compose music. 
For a better understanding of the actual implementation of this curriculum, I have presented one of the seven units below (Figure 1) in order to provide details about the curriculum and the teaching of natural appreciation.

\section{Subject: Dancing with Tree}

\begin{tabular}{|l|l|}
\hline \multirow{3}{*}{ Course Objectives } & $\begin{array}{l}\text { 1. Students are able to appreciate the beauty of nature in depth through senses, } \\
\text { sciences, imagination, participation, myths, folktales, and arts. } \\
\text { 2. Students are able to express the beauty of nature through creative writing, painting, } \\
\text { music, drama, etc. }\end{array}$ \\
\hline
\end{tabular}

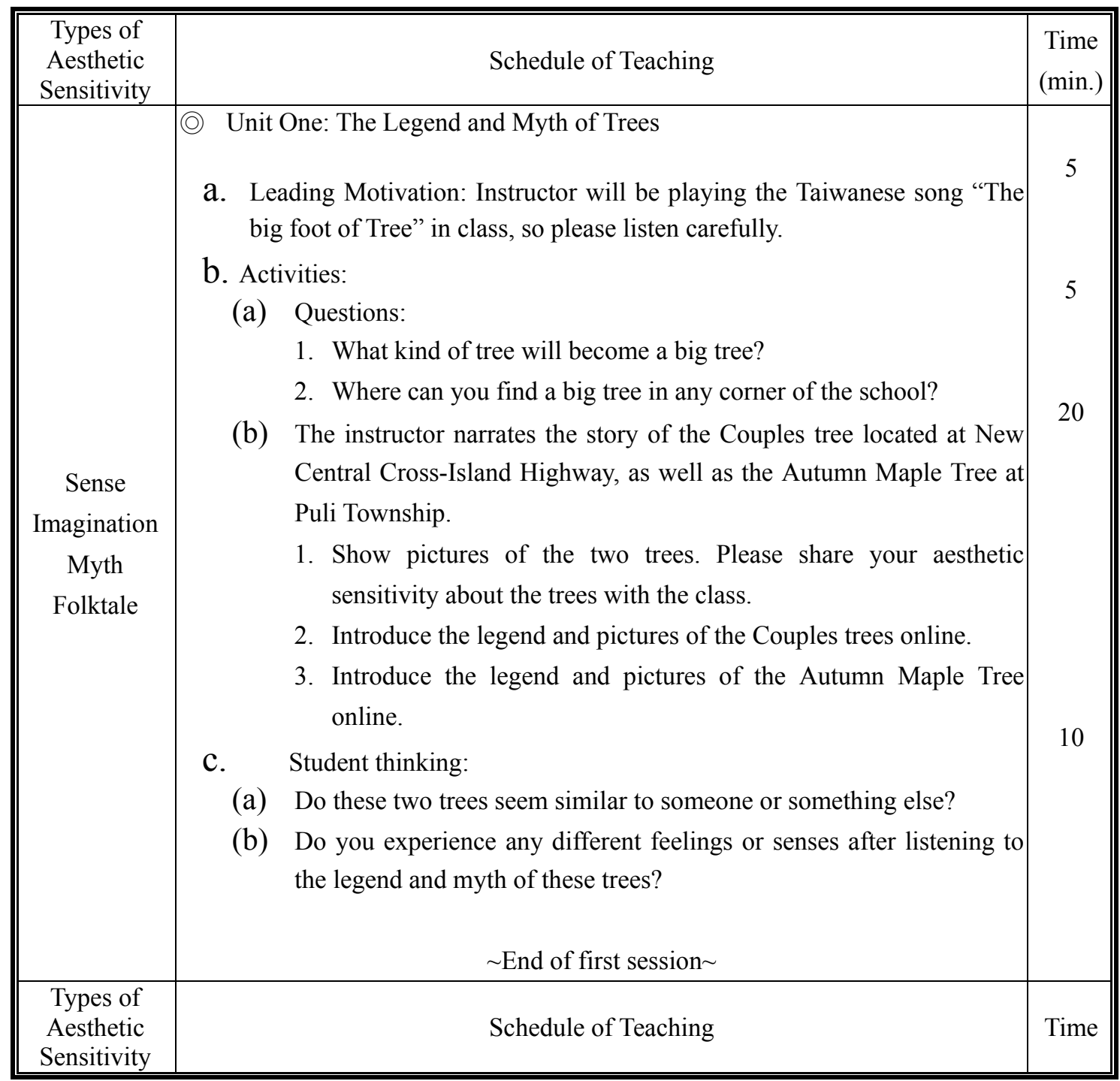




\begin{tabular}{|c|c|c|}
\hline $\begin{array}{c}\text { Senses } \\
\text { Imagination } \\
\text { Engagement } \\
\text { Arts }\end{array}$ & $\begin{array}{l}\text { Unit Two: It is Nice to Meet the Tree } \\
\text { a. Leading Motivation: Display poem (p.p.t), "The Song of Big Tree," } \\
\text { written by Harry Behn. } \\
\text { b. Activities: } \\
\text { (a) The instructor reads the poem aloud once, and then the students } \\
\text { follow. } \\
\text { (b) Explain the following phase from the poem: "Tree is that fine and } \\
\text { beauty, trees they don't shout nor noisy, just grow quietly. Beneath } \\
\text { the tree covers with shady green shade for the napping cows, and the } \\
\text { tiptop gently embrace baby birds..." } \\
\text { Questions: } \\
\text { (a) What do you feel about trees after listening to the poem? } \\
\text { (b) Have you had any memorable experiences with trees? Which kind of } \\
\text { tree do you think is the finest one? } \\
\text { (c) Break into groups search for the most beautiful tree on campus, and } \\
\text { then take a photo of it. } \\
\text { d. Ending activities: } \\
\text { (a) Introduce the tree you chose, including the name, location, } \\
\text { characteristics, etc. } \\
\text { (b) Imagine what the tree looks like, and explain why you think it is } \\
\text { beautiful. }\end{array}$ & yy \\
\hline $\begin{array}{c}\text { Types of } \\
\text { Aesthetic } \\
\text { Sensitivity }\end{array}$ & Schedule of Teaching & Time \\
\hline $\begin{array}{l}\text { Senses } \\
\text { Myth } \\
\text { Folktale } \\
\text { Imagination } \\
\text { Engagement } \\
\text { Science }\end{array}$ & $\begin{array}{l}\text { (a) Unit Three: The Guidance Angel of the Tree - understands it and loves it. } \\
\text { a. Leading motivation: Which trees are able to blossom on campus? Use the } \\
\text { introduction website of "Plants on campus" photographs, including photos } \\
\text { of the Cotton Tree, the Kassod Tree, the Camphor Tree, the Floss-silk } \\
\text { Tree, etc. Please make a short presentation on these trees, including an } \\
\text { explanation about which part of the tree you think is pretty, as well as } \\
\text { what or whom those blossom trees remind you of/seem similar with. } \\
\text { b. Activities: explain the six major organs (root, stem, leave, flower, fruit, } \\
\text { and seed) of the general plants in depth, providing a description that } \\
\text { incorporates knowledge of botany and ecology. } \\
\text { Conclusion: sharing experiences. Please review the previous pictures you } \\
\text { (the students) saw, and compare your feelings before and after the } \\
\text { explanation of the structure of plants. } \\
\text { End of Third Session }\end{array}$ & 10 \\
\hline
\end{tabular}




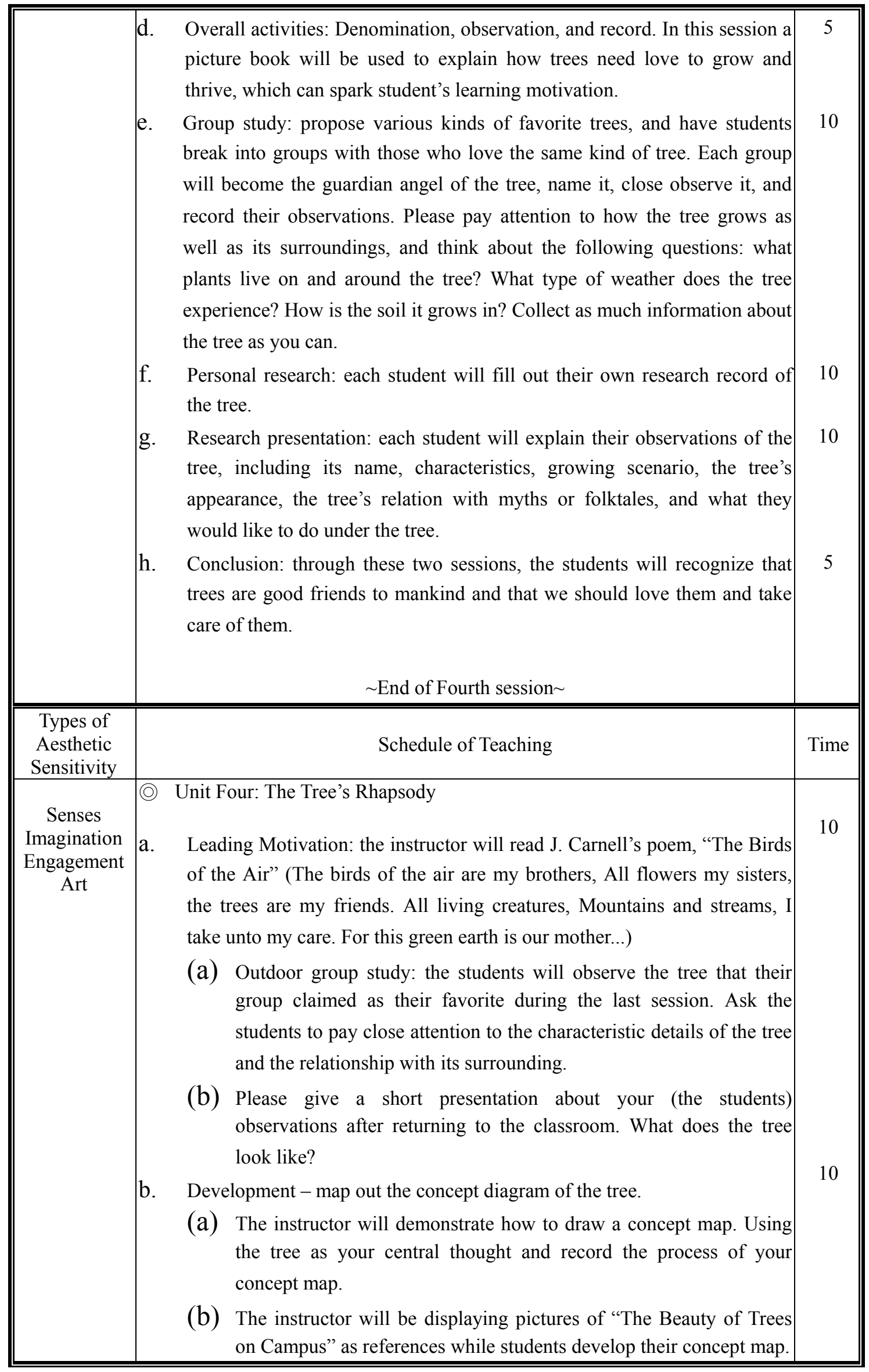




\begin{tabular}{|c|c|c|}
\hline & $\begin{array}{l}\text { (c) Concept map presentation. } \\
\text { c. Overall activities - Tree in the eyes of poetry. } \\
\text { (a) The instructor will ask students to read out loud poems from the } \\
\text { Tang dynasty as well as the "Poem of Tree" by the poets Wuxian Lin } \\
\text { and Liang Lin. Please tell the classroom your favorite phrase and the } \\
\text { reason why it is your favorite part of the poem. } \\
\text { (b) Please explain the differences between appreciation of nature's } \\
\text { beauty through poetry and through direct contact. } \\
\sim \text { End of Fifth session }\end{array}$ & 20 \\
\hline $\begin{array}{c}\text { Types of } \\
\text { Aesthetic } \\
\text { Sensitivity }\end{array}$ & Schedule of Teaching & Time \\
\hline $\begin{array}{c}\text { Senses } \\
\text { Imagination } \\
\text { Art }\end{array}$ & $\begin{array}{l}\text { (0) Unit Five: Write Poem for Tree } \\
\text { Leading motivation - the instructor will demonstrates various kinds of fine trees } \\
\text { to expand student's imagination and appreciation about trees through a } \\
\text { PowerPoint presentation. } \\
\text { a. The instructor will randomly select vocabularies from students' concept } \\
\text { maps. Each group chooses one, turns it into a complete sentence, and then } \\
\text { writes it down on the paper. } \\
\text { b. Present the sentences on the blackboard and ask each group to discuss the } \\
\text { arrangement of these sentences. The class shall create a poem with the tree } \\
\text { as the theme. } \\
\text { c. Using the method just demonstrated in the class, each student should } \\
\text { create his poem about the tree through the clues in his own concept map. } \\
\text { d. Sharing, reading, and enjoying others' work. } \\
\quad \sim \text { End of Sixth session }\end{array}$ & 10 \\
\hline $\begin{array}{c}\text { Types of } \\
\text { Aesthetic } \\
\text { Sensitivity } \\
\end{array}$ & Schedule of Teaching & Time \\
\hline $\begin{array}{c}\text { Senses } \\
\text { Imagination } \\
\text { Engagement }\end{array}$ & $\begin{array}{l}\text { (a) Unit Six: I am a Tree } \\
\text { a. Leading Motivation } \\
\text { (a) Read "Share the joy of nature" p. 182, "The Root going down, down } \\
\text { to the deep moist soil. Yet going further down, drilling down, firmly } \\
\text { tighten me here..." } \\
\text { (b) Outdoor Recreation. Experience the beauty of trees through the } \\
\text { principle of flow learning. } \\
\text { b. Development } \\
\text { (a) Break into groups and sit around the tree; appreciate the tree quietly. } \\
\text { (b) The instructor will be playing nature-related music, and will read the } \\
\text { poem "Share the joy of nature" on p. 182. }\end{array}$ & 15 \\
\hline
\end{tabular}




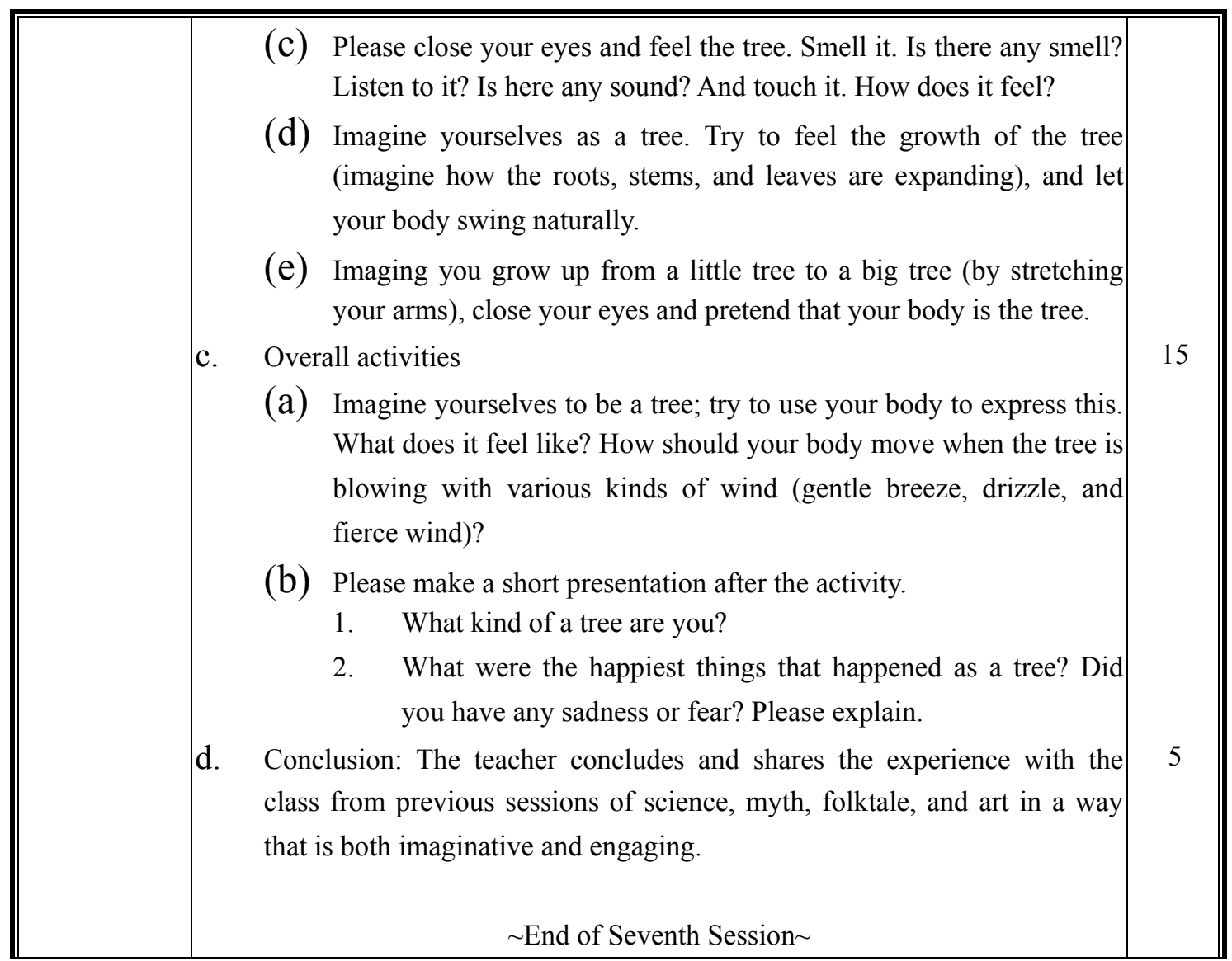

Figure 1. An example of one curriculum unit

\section{Conclusion}

Nature is humanity's best teacher. We will learn more if we know how to appreciate nature. I have introduced nine principles from the theories of the Western aesthetics of nature. These principles can enlarge the breadth and depth of natural appreciation compared to a more general approach based on sense experience. I also show examples of concrete curriculum and teaching for elementary school students. Teachers may refer to these principles and curriculum to construct different natural aesthetic curricula according to the context of their school. The school principal can design a school-based curriculum from grade 1 to grade 6 and become a special character on behalf of the school. Researchers may further examine the effects of curriculum implementation on environmental, moral, and life education in order to understand what students have learned and what problems may need to be addressed.

\section{Acknowledgments}

The research is financed by Ministry of Science and Technology, Taiwan, R. O. C., Project No. 101-2410-H-018-016.

\section{References}

Berleant, A. (1997). Living in the landscape: Toward an aesthetics of environment. University of Kansas Press.

Brady, E. (1998). Imagination and the aesthetic appreciation of nature. The Journal of Aesthetics and Art Criticism, 56(2), 139-147. http://dx.doi.org/10.2307/432252

Brady, E. (2003). Aesthetics of the natural environment. Tuscaloosa: The University of Alabama Press.

Carlson, A. (2002a). Aesthetics and environment: The appreciation of nature, art and architecture. London: Routledge.

Carlson, A. (2002b). Nature appreciation and the question of aesthetic relevance. In A. Berleant (Ed.), Environment and the arts: Perspectives on environmental aesthetics (pp. 61-74). Burlington, VT: Ashgate.

Carlson, A. (2009). Nature and landscape: An Introduction to environmental aesthetics. New York: Columbia 
University Press.

Carroll, N. (2004). On being moved by nature: Between religion and natural history. In A. Carlson, \& A. Berleant (Eds.), The aesthetics of natural environments (pp. 89-107). Canada: Broadview Press.

Chang, T.-C. (2001). Curriculum design of environmental education. Taipei, Taiwan: National Taiwan Norm University.

Cornell, J. (1998). Sharing nature with children. Nevada City, Calif.: Dawn Publications.

Cun Dong Elementary School. (2014). Knowing plants in campus. Retrieved July 10, 2014, from $\mathrm{http} / / / 163.23 .112 .188 /$ nature/kuo/k-7/f1.htm

Department of Education. (2008). 2008: Grade 1-9 Curriculum Guidelines. Retrieved May 26, 2014, from http://teach.eje.edu.tw/9CC2/9cc_97.php

Hepburn, R. (2004). Landscape and the metaphysical imagination. In A. Carlson, \& A. Berleant (Eds.), The aesthetics of natural environments (pp. 127-140). Canada: Broadview Press.

Rolston III, H. (1995). Does aesthetic appreciation of landscapes need to be science-based? British Journal of Aesthetics, 35, 374-386.

Rolston III, H. (1998). Aesthetic experience in forests. The Journal of Aesthetics and Art Criticism, 56(2), 157-166. http://dx.doi.org/10.2307/432254

Rolston III, H. (2000). Aesthetics in the swamps. Perspectives in Biology and Medicine, 43(4), 584-597. http://dx.doi.org/10.1353/pbm.2000.0052

Rolston III, H. (2011). Celestial aesthetics: Over our heads and/or in our heads. Theology and Science, 9(3), 273-285. http://dx.doi.org/10.1080/14746700.2011.587663

Saito, Y. (2004). Appreciating nature on its own terms. In A. Carlson, \& A. Berleant (Eds.), The aesthetics of natural environments (pp. 141-155). Canada: Broadview Press.

Thoreau, H. D. (1990). Walden. Philadelphia, Pa.: Courage Books.

Tu, M. (2009). Flow learning. Retrieved March 16, 2014, from http://ylib.com/author/twu/listen1.htm

\section{Notes}

Note 1. I will engage in a deeper discussion of contents and debates of two approaches in the other article. For the aim of this article, I will focus more on curriculum design, not process of theoretical arguments and dialectics.

Note 2. The theory of Rolston can be regarded as the special comprehensive approach for the emphasis on sciences, engaged participation and religious experience. See Carlson \& Berleant (Eds.) (2004). But basically, Rolston stresses natural sciences more than others.

Note 3. It means to obtain aesthetic sensitivity through the senses, which is the same as other elements.

\section{Copyrights}

Copyright for this article is retained by the author(s), with first publication rights granted to the journal.

This is an open-access article distributed under the terms and conditions of the Creative Commons Attribution license (http://creativecommons.org/licenses/by/3.0/). 